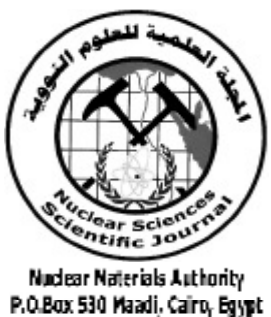

ISSN 2314-5609

Nuclear Sciences Scientific Journal

6, 181-190

2017

http://www.ssnma.com

\title{
ACID LEACHING OF URANIUM FROM KAOLINIZED GRANITE OF EL SELA AREA, SOUTH EASTERN DESERT, EGYPT
}

\author{
MOHAMED DEMERDASH, REDA A. GHAZALA and MONA M. FAWZY \\ Nuclear Materials Authority, P.O. Box 530, El-Maadi, Cairo, Egypt
}

\begin{abstract}
El Sela area is one of the promising localities for the occurrences of uranium mineralization in the granitic rocks of the south Eastern Desert of Egypt. The area is a good example for highly altered samples as hematitization, espisyenitization and argillic alteration. The main purpose of this work is to answer for a question "Is the physical separation techniques for the highly altered samples more effective in the leaching efficiency of uranium than the original sample?" to answer on this question it is necessary to study the characteristics of uranium leaching using sulfuric acid from a representative sample of this ore material assaying about $0.454 \%$ uranium and optimize the relevant factors then comparing between the leaching efficiency of the original sample versus the leaching efficiency of the physical beneficiated products. The optimum conditions for uranium leachability on the original sample reached $98 \%$ after 2 hours agitation time using $60 \mathrm{~g} \backslash 1$ sulphuric acid concentration, $1: 3$ solid $\backslash$ liquid ratio and $-0.1 \mathrm{~mm}$ grain size at $80^{\circ} \mathrm{C}$. On the other hand the same optimum conditions applied on the physical beneficiated products and the leaching efficiency reached to about $98 \%$ for sink fraction and about $98 \%$ for float fraction which proved that there is no requirement for the prior physical beneficiation of the highly altered sample.
\end{abstract}

\section{INTRODUCTION}

Several promising uranium occurrences have actually been discovered in various Egyptian localities in the Eastern Desert and Sinai in association with mainly igneous or sedimentary host rocks. El Sela area is one of the most promising uranium occurrences being located in the south Eastern Desert at about $20 \mathrm{~km}$ west of Abu Ramad town and is bounded by lat. $22^{\circ} 13^{\prime}-22^{\circ} 20^{\prime} \mathrm{N}$ and long. $36^{\circ}$ $08^{\prime}-36^{\circ} 17^{\prime} \mathrm{E}$ (Fig. 1). El Sela granite is injected by several microgranite and mineralized quartz veins besides some basic dykes and its northern part is relatively more enriched in uranium. The area is actually dissected by two shear zones that show appreciable wall rock alterations including hematitization, espisy- enitization and argillic alteration (Ibrahim et al, 2003).

Uranium is a relatively abundant element where its assay in the earths crust attains about $4 \mathrm{ppm}$ and is characterized by having the highest atomic number of all the naturally-occurring elements, besides having a complex mineralogy

Uranium is one of the important metal values which is used as a fuel in the nuclear power reactors for producing electrical energy. Global electrical generation provided by nuclear energy is expected to increase from 2.6 trillion Kilowatt hour in 2008 up to 4.9 trillion Kilowatt hour in 2035 (EIA, 2011); a matter which reflects the importance of uranium industry. 


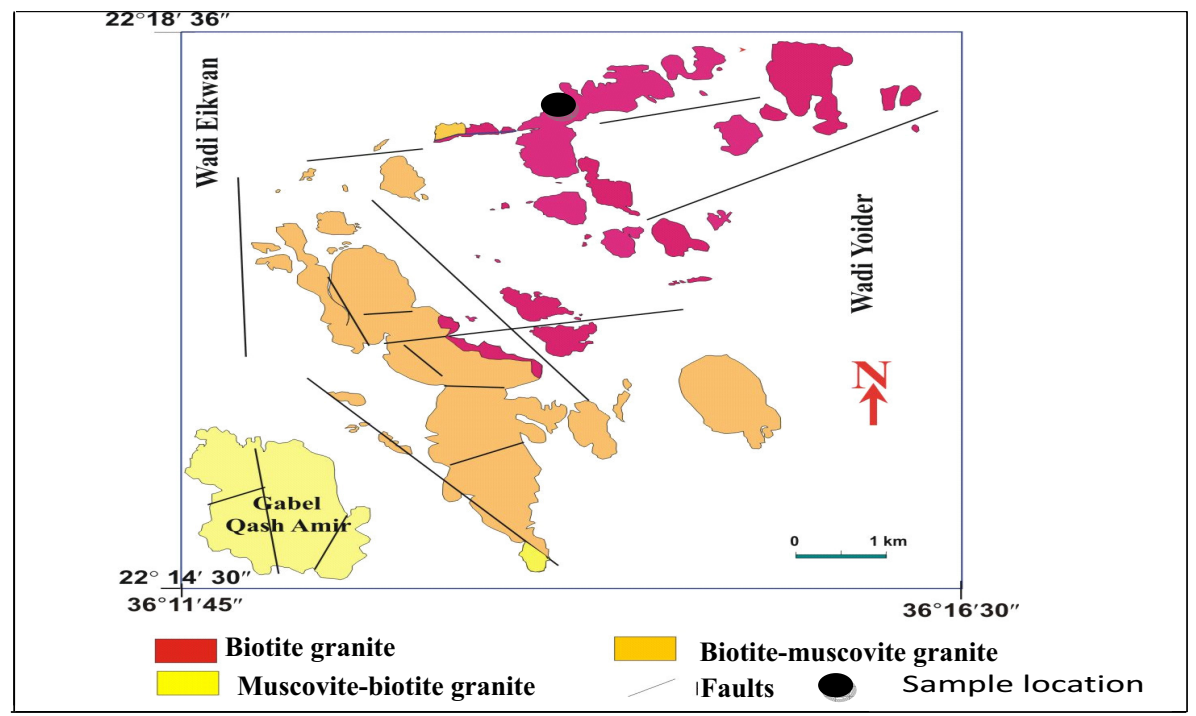

Fig. 1: Geologic map of El Sela Area (After Abdel Meguid, et al., 2003)

According to Merritt (1971) and to the IAEA technical report (1993), leaching represents the first step in the processing of uranium ores due to the fact that its minerals are either finely distributed in the ore components or the uranium in such ores might be adsorbed upon some of their components in a manner that physical upgrading would not be useful. The purpose is to leach or dissolve the uranium from its bearing minerals in the ore. The selection of a leaching procedure depends in a part on the physical characteristics of the ore which mainly include the type of mineralization, the ease of liberation and the nature of the other constituent minerals present.

The ores are thus subjected to direct leaching using either acid or alkaline reagents where sulfuric and or a mixture of sodium carbonate/bicarbonate are commonly used depending mainly upon the ore composition. The chemistry of uranium sulfuric acid leaching can be summarized as follows:

$$
\begin{aligned}
& \mathrm{UO}_{3}+\mathrm{H}_{2} \mathrm{SO}_{4}=\mathrm{UO}_{2} \mathrm{SO}_{4}+\mathrm{H}_{2} \mathrm{O} \\
& \mathrm{UO}_{2}+1_{2} \mathrm{O}_{2}+\mathrm{H}_{2} \mathrm{SO}_{4}{ }^{2-}=\mathrm{UO}_{2} \mathrm{SO}_{4}+\mathrm{H}_{2} \mathrm{O}
\end{aligned}
$$

$$
\begin{aligned}
& \mathrm{UO}_{2} \mathrm{SO}_{4}+\mathrm{SO}_{4}^{2-}=\left[\mathrm{UO}_{2}\left(\mathrm{SO}_{4}\right)_{3}\right]^{2-} \\
& \mathrm{UO}_{2}\left(\mathrm{SO}_{4}\right)^{2-}+\mathrm{SO}_{4}^{2-}=\left[\mathrm{UO}_{2}\left(\mathrm{SO}_{4}\right)_{3}\right]^{4-}
\end{aligned}
$$

From the obtained leach liquors, uranium is essentially extracted versus anion exchange resins or else via solvent extraction using either organic amines or cationic organophosphorous compounds. After proper elution uranium would be precipitated in the form of a highly pure concentrate which is generally referred to as the yellow cake.

The uranium precipitation reaction is chemically shown as:

$$
2 \mathrm{UO}_{2} \mathrm{SO}_{4}+6 \mathrm{NaOH}=\mathrm{Na}_{2} \mathrm{U}_{2} \mathrm{O}_{7}+2 \mathrm{Na}_{2} \mathrm{SO}_{4}+3 \mathrm{H}_{2} \mathrm{O}
$$

Yousef et al, (2013) has studied the extraction of uranium from treated technological sample of El Sela Area by aqueous nitrate solution using the organic extractant tributyl phosphate (TBP) or 1,4 Dioxane dissolved in different diluents through which the leaching process was carried out using sulphuric acid under moderate conditions of $75 \mathrm{~g} / 1$, solid/liquid ratio $1 / 1.5$ and agitation for 6 hours at $45^{\circ} \mathrm{C}$ being the heat of dilution gen- 
erated due to addition of concentrated sulphuric acid to the slurry. Abd Elaal, (2006), has optimized the sulfuric acid agitation leaching on El Sella area located at about $20 \mathrm{~km}$ west of Abu Ramad City covering an area of about $128 \mathrm{~km}^{2}$ results in $300 \mathrm{~g} / \mathrm{l} \mathrm{H}_{2} \mathrm{SO}_{4}$, agitation time $4 \mathrm{hrs}, \mathrm{S} / \mathrm{L}$ ratio $1 / 2$, grain size -200 mesh, and $100^{\circ} \mathrm{C}$ as leaching temperature.

In the present work, a representative technological sample of kaolinized granite of El Sela ore material is studied. The studied sample is mainly characterized by enrichment in kaolinite and was found to assay about $0.454 \%$ uranium. This ore material sample has been subjected to a detailed uranium leaching study to optimize the relevant agitation leaching factors of the bulk sample. In addition to applying these optimum conditions on the leaching of uranium on the beneficiated products and then determine which of them reached to maximum leachability. Further, the leaching data obtained was compared with the results obtained from leaching of beneficiated products for similar ore sample.

\section{EXPERIMENTAL}

\section{Material Characterization Chemical analysis}

The collected technological sample from sela ore was ground to mesh size of 200 mesh. Proper quartering of the technological sample was performed after grinding to less than 200 mesh size to obtain a representative sample which was subjected to complete chemical analysis of both major and trace elements content. For the former, the conventional wet chemical technique was applied (Shapiro and Brannock, 1962) where $\mathrm{SiO}_{2}, \mathrm{Al}_{2} \mathrm{O}_{3}, \mathrm{TiO}_{2}$ and $\mathrm{P}_{2} \mathrm{O}_{5}$ were determined using their relevant spectrophotometic methods while $\mathrm{Na}_{2} \mathrm{O}$ and $\mathrm{K}_{2} \mathrm{O}$ were assayed by the flame photometric technique. Total $\mathrm{Fe}$ as $\mathrm{Fe}_{2} \mathrm{O}_{3}, \mathrm{MgO}$ and $\mathrm{CaO}$ were determined by titration methods against dichromate and EDTA solutions, respectively. The loss on ig- nition (L.O.I) was gravimetrically determined at $550{ }^{\circ} \mathrm{C}$ for $\mathrm{H}_{2} \mathrm{O}, \mathrm{H}_{2} \mathrm{O}$ and organic matter as well as at $1000^{\circ} \mathrm{C}$ for $\mathrm{CO}_{2}$. The estimated error for these major constituents is not more than $\pm 1 \%$.

The trace elements $\mathrm{V}, \mathrm{Cr}, \mathrm{Ni}, \mathrm{Cu}, \mathrm{Zn}, \mathrm{Ga}$, $\mathrm{Rb}, \mathrm{Sr}, \mathrm{Y}, \mathrm{Zr}, \mathrm{Nb}, \mathrm{Pb}$ and $\mathrm{Ba}$ were also analyzed at the laboratories of the Nuclear Materials Authority by the X-ray fluorescence technique (XRF) using Philips Unique II unit fitted with an automatic sample changer PW 1510 (30 position), connected to a computer system using X-40 program for spectrometry. With respect to uranium determination in the working sample and in all the stream solutions of the leaching process, it was carried out using the ferrous ammonium metavanadate oxidimetry method (Hefnawy et al, 2002).

\section{Mineral identification}

For identifying the mineral composition, a proper sample portion of the collected technological sample of kaolinized granite of El Sela area was subjected to conventional mineral separation procedure using bromoform $\left(2.85 \mathrm{gm} / \mathrm{cm}^{3}\right)$. From the obtained heavy and light fractions, different mineral grains were picked up for their identification using $\mathrm{X}$-ray diffraction (XRD) technique. For this purpose, a Philips PW $1730 \mathrm{X}$-ray generator with Ni-filtered $\mathrm{Cu} \mathrm{K} \alpha$ radiation $\left(\lambda=1.54 \mathrm{~A}^{\circ}\right)$ was run at $40 \mathrm{KV}$ and $25 \mathrm{~A}^{\circ}$ and T.C. $2 \mathrm{sec}$.

\section{Agitation Leaching Procedures}

\section{Agitation leaching on bulk ore sample}

Each agitation leaching experiment was carried out by mixing a proper weight of the working ore material sample with a certain volume of sulfuric acid solution at varying concentrations. The obtained slurry was then agitated at the required temperature for a certain contact time followed by its filtration and the residue left behind was washed with distilled water and both the filtrate and the washing liquor were collected to a proper volume 
for uranium analysis. Several leaching experiments have been undertaken to optimize the relevant agitation leaching factors; namely the acid concentration, the contact time, the solid/liquid ratio besides the ore particle size and the leaching temperature.

\section{Agitation leaching on beneficiated products}

Masoud et al. (2012) studied the physical beneficiation of the same sample of this work of the kaolinized granite sample of El Sela area by froth flotation technique and the best result of reverse flotation was obtained by using sodium dodecyl sulphate as a collector and sodium hexameta phosphate as a dispersant and which has resulted in a float fraction that mainly contained kaolinite and quartz and a sink fraction in which secondary uranium minerals has been upgraded. The uranium assay in the latter $(64.7 \%$ weight percent) has attained $0.63 \%$ whereas its assay in the float fraction $35.3 \%$ weight percent) was decreased to $0.14 \%$.

The determined optimum conditions of the agitation leaching on the bulk sample procedure were then applied on the beneficiated products (float and sink) of the ore sample that have been obtained by the froth flotation technique.

\section{RESULTS AND DISCUSSION}

\section{Ore Material Characteristics Chemical composition}

The obtained results of the chemical analysis of the major oxides of the studied kaolinized granite representative ore material sample are reported in Table (1). From the latter, it is clearly evident that the silica in the original granite assayed about 58\% while the alumina content is found to assay about $17 \%$ that reflecting the formation of the clay minerals at the expense of the feldspar constituents. In the meantime, the ferric iron oxide and the lime contents have been found to approach about 6 and $4.5 \%$ respectively.
Table 1: Major oxides of the studied representative sample of the studied kaolinized granite, El Sela area

\begin{tabular}{lrrrrrrrrrr}
\hline \multicolumn{10}{c}{ Major oxides analysis (Wt. \%) } \\
\hline $\mathrm{Si}_{2}$ & $\mathrm{Al}_{2} \mathrm{O}_{3}$ & $\mathrm{Fe}_{2} \mathrm{O}_{3}$ & $\mathrm{Mg0}$ & $\mathrm{Ca} 0$ & $\mathrm{Na}_{2} \mathrm{O}$ & $\mathrm{K}_{2} \mathrm{O}$ & $\mathrm{Ti}_{2}$ & $\mathrm{P}_{2} \mathrm{O}_{5}$ & L.0.I & Total \\
57.71 & 16.85 & 5.86 & 1.61 & 4.48 & 0.67 & 1.98 & 0.30 & 0.12 & 10.28 & 99.89 \\
\hline
\end{tabular}

In this regard, it is interesting to indicate that the L.O.I achieved at $1000{ }^{\circ} \mathrm{C}$ for $2 \mathrm{hr}$ which attained about $10.3 \%$ would indeed reflect the combined water of the formed clay minerals besides possible gypsum together with $\mathrm{CO}_{2}$ of possible dolomite. Also, the alkali metal oxides attaining about $2 \%$ for $\mathrm{K}_{2} \mathrm{O}$ and about 0.7 for $\mathrm{Na}_{2} \mathrm{O}$ might represent the remaining potash feldspar and albite besides possible partial absorption upon the clay mineral.

On the other hand, the analytical results of some trace elements (Table 2 ) have revealed the presence of $\mathrm{Pb}$ and $\mathrm{Zn}$ attaining 382 and $361 \mathrm{ppm}$, respectively besides $\mathrm{Ga}$ and $\mathrm{V}$ at the extent of 47 and 88 ppm, respectively. Apart from $\mathrm{Zr}$ and $\mathrm{Ba}$ assaying more than $500 \mathrm{ppm}$, $\mathrm{Sr}$ was found to assay up to $783 \mathrm{ppm}$. In a reference to possible presence of multiple oxide minerals containing uranium and rare earth elements, an assay of about 262 ppm Nb has been indicated.

\section{Mineralogical Composition}

Gharib et al. (2013) studied the mineralogical composition of the same sample of kaolinized granite of El Sela area and they found

Table 2: Trace elements analysis of the studied representative sample of the kaolinized granite , El Sela area

\begin{tabular}{rrrrrrrrrrrrr}
\hline \multicolumn{11}{c}{ Trace elements analysis (ppm) } \\
\hline $\mathrm{Cr}$ & $\mathrm{Ni}$ & $\mathrm{Cu}$ & $\mathrm{Zn}$ & $\mathrm{Zr}$ & $\mathrm{Y}$ & $\mathrm{Ba}$ & $\mathrm{Pb}$ & $\mathrm{Sr}$ & $\mathrm{Ga}$ & $\mathrm{V}$ & $\mathrm{Nb}$ & $\mathrm{U}$ \\
13 & 14 & 12 & 361 & 502 & 66 & 522 & 382 & 783 & 47 & 88 & 262 & 4540 \\
\hline
\end{tabular}


that the main constituents of the heavy fraction grains representing about $4 \mathrm{wt} \%$, include the secondary uranium minerals uranophane(Fig. 2 ), meta-autunite (Fig. 3) and phurcolite (Fig. 4). Also uranium bearing minerals as uranothorite and zircon and finally non-radioactive minerals as fluorite (Fig. 5), sphene, fergusonite, and apatite were recorded in lesser amounts. On the other hand, the light fraction was also subjected to X-ray diffraction analysis and it is revealed that feldspar minerals besides kaolinite, gypsum and quartz are the main constituents (Figs. 6\&7).

As a matter of fact, the mineralogical study has indeed revealed that uranium occurs in two modes of occurrence; namely a mineralized Form representing by the uranophane, the meta-autunite and the phurcolite minerals while the second one is manifested in the form of uranium adsorbed on the surface of kaolinite. The latter form was confirmed through using Gamma ray spectrometric analysis of the light fraction which represented $32 \%$ of the uranium assay in the studied sample (Gharib, et al., Op. Cit).

On the other hand, it is interesting to indicate that according to the obtained chemical analysis (Table 1) and the above mentioned XRD mineralogical data (Figs.2-7), the po-

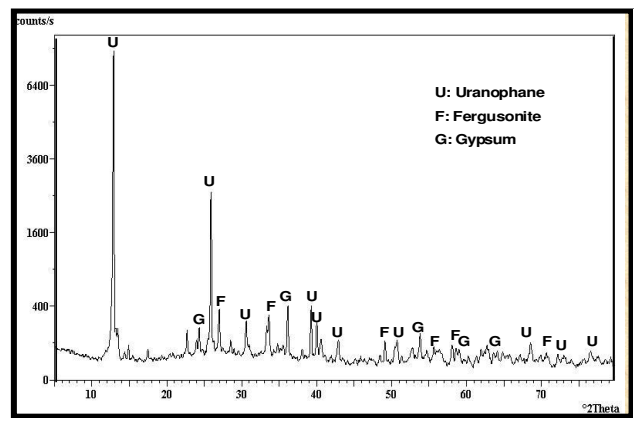

Fig.2: X-ray diffraction pattern of the heavy and light fractions of the kaolinized granite of El Sela sample showing uranophane, fergusonite and gypsum (After, Gharib et al., 2013)

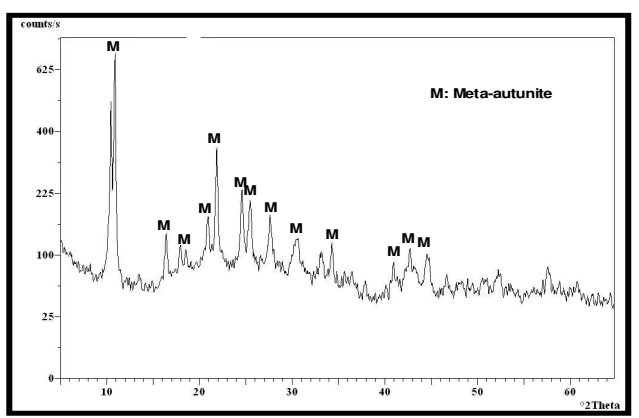

Fig.3: X-ray diffraction pattern of the heavy and light fractions of the kaolinized granite of El Sela sample showing meta-autunite (After, Gharib et al., 2013)

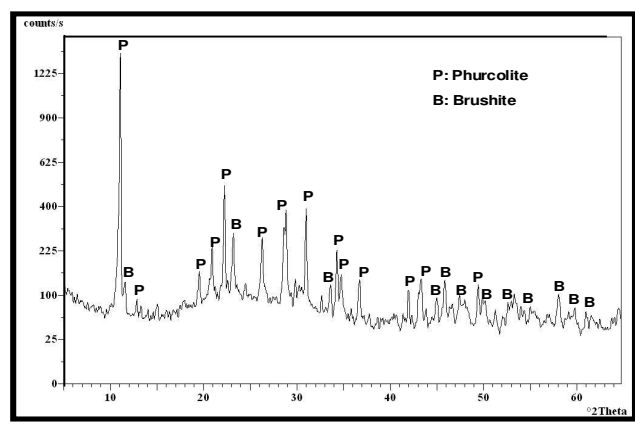

Fig.4: X-ray diffraction pattern of the heavy and light fractions of the kaolinized granite of El Sela sample showing phurcolite and brushite (After, Gharib et al., 2013)

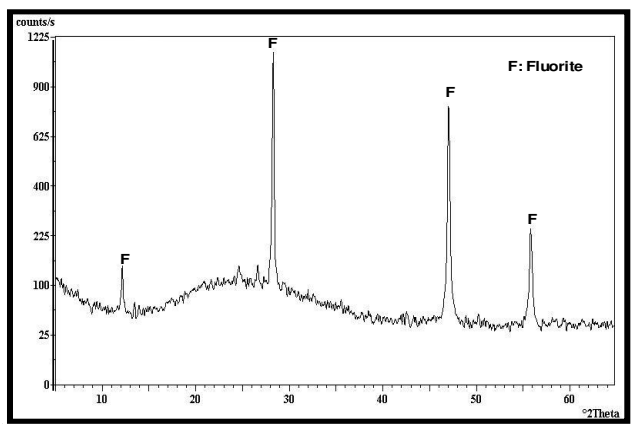

Fig.5: X-ray diffraction pattern of the heavy and light fractions of the kaolinized granite of El Sela sample showing fluorite (After, Gharib et al., 2013) 


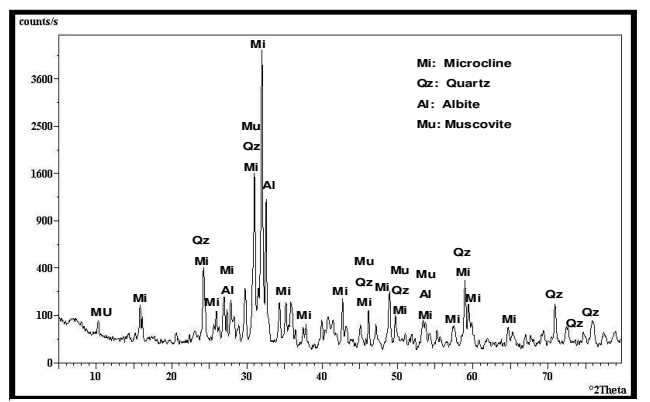

Fig.6: X-ray diffraction pattern of the heavy and light fractions of the kaolinized granite of El Sela sample showing microcline, quartz, albite and muscovite (After, Gharib et al., 2013)

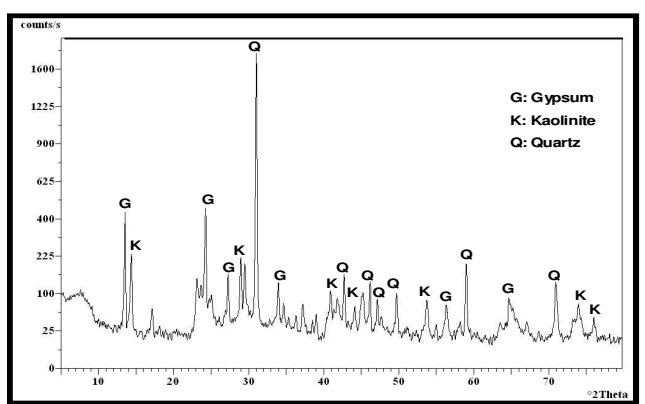

Fig.7: X-ray diffraction pattern of the heavy and light fractions of the kaolinized granite of El Sela sample showing quartz, gypsum and kaolinite (After, Gharib et al., 2013)

tential mode of the studied technological sample was calculated and listed in Table (3). From the latter, it is quite clear that the high percent of kaolinite, about $34 \%$ and iron oxides (about 6\%), may cause obstruction in the leaching of uranium and the presence of gypsum with about $6.7 \%$ cause higher consumption of acid in leaching of uranium.

\section{Results of Uranium Leaching}

\section{The bulk agitation leaching}

The optimum conditions for the bulk agitation leaching efficiency of uranium from
Table 3: Potential mineralogical composition of the studied technological sample of kaolinized granite, El Sela area

\begin{tabular}{lrlllllr}
\hline Mineral & Kaolinite & Quartz & Microcline & Allite Dolomite Gypsum & $\begin{array}{r}\text { Iron } \\
\text { oxides }\end{array}$ \\
\hline Wt. $(\%)$ & 34.3 & 30.4 & 11.6 & 5.7 & 7.4 & 6.7 & $\mathbf{5 . 9}$ \\
\hline
\end{tabular}

the studied kaolinized granite ore material of El Sela area have been determined by studying the effects of the different relevant parameters that would affect the leaching efficiency. These included the effects of the sulfuric acid concentration, the agitation time, the solid/liquid ratio, the effect of the particle size and temperature.

\section{Effect of sulfuric acid concentration}

The effect of acid concentration upon the uranium leaching efficiency from the study ore sample was carried out at different acid concentrations in the range of 20 to $100 \mathrm{~g} / \mathrm{l}$ under fixed conditions of a solid/ liquid ratio of $1: 3$ for 2 hours agitation time at $25^{\circ} \mathrm{C}$ and using a grain size range of $(-0.2 \mathrm{~mm}),(+0.1 \mathrm{~mm})$. The leaching efficiency of uranium which are given on Fig. (8), indicate that the favorable concentration is $60 \mathrm{~g} / \mathrm{l}$ for uranium leaching. Under these conditions, the leaching efficiency of uranium has attained $80 \%$. While $80 \mathrm{~g} /$

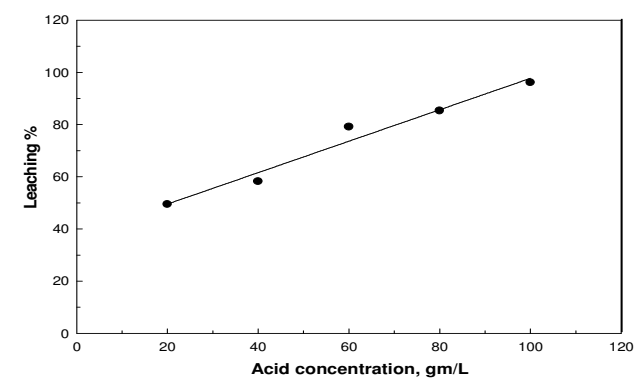

Fig.8: Effect of sulfuric acid concentration on the leaching percent of uranium from the studied kaolinized granite of El Sela ore material 
$\mathrm{L}$ acid concentration did not markedly affect the uranium leaching efficiency.

\section{Effect of agitation time}

The effect of agitation time upon U leaching efficiency was studied in the range from $1 / 2$ to 4 hours at fixed conditions of $(-0.2$ $+0.1) \mathrm{mm}$ grain size at $25^{\circ} \mathrm{C}$ with $60 \mathrm{~g} / \mathrm{l}$ acid concentration in a solid liquid ratio of 1:3. The obtained results are plotted on Fig. (9). It is observed that about $75 \%$ of uranium leaching efficiency in the first half hour and about 80 and $81 \%$ in the first and second hours, respectively. However, leaching effeciency was decreased to about 79 and $75 \%$ in the third and fourth hours respectively. This decrease is most probably due to the fact that increasing the contact time would allow the possibility of uranium re-adsorption upon the surface of the kaolinite and hematite mineral surface; a matter which necessitates relatively large quantities of acid to raise the dissolution ratio and other vigorous conditions to affect the surface properties of the slurry. Therefore, 2 hours agitation time for acid leaching of uranium for the studied sample would be considered the optimum result $(81 \%)$.

\section{Effect of solid/liquid ratio}

The effect of solid/liquid ratio upon the uranium leaching efficiency from the studied ore material was examined in the range from $1 / 1$ to $1 / 4$ ratio under fixed conditions of $60 \mathrm{~g} / 1$ acid concentration, 2 hours agitation time, $(-0.2+0.1) \mathrm{mm}$ grain size at $25^{\circ} \mathrm{C}$. The obtained results plotted on Fig. (10) indicate that $1 / 3 \mathrm{~S} / \mathrm{L}$ ratio is a suitable ratio for a uranium dissolution efficiency of about $79.1 \%$ and which slightly increased to $83.5 \%$ by decreasing the $\mathrm{S} / \mathrm{L}$ ratio to $1 / 4$.

\section{Effect of particle size}

Sufficient liberation of the uranium from its minerals is required to be exposed to the acid leaching reagent; however, overgrinding may result in increased pulp viscosity and in

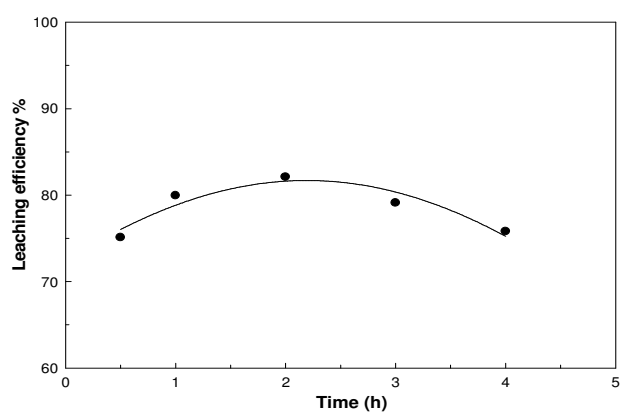

Fig.9: Effect of agitation time on the leaching percent of uranium from the studied El Sela kaolinized granite ore material

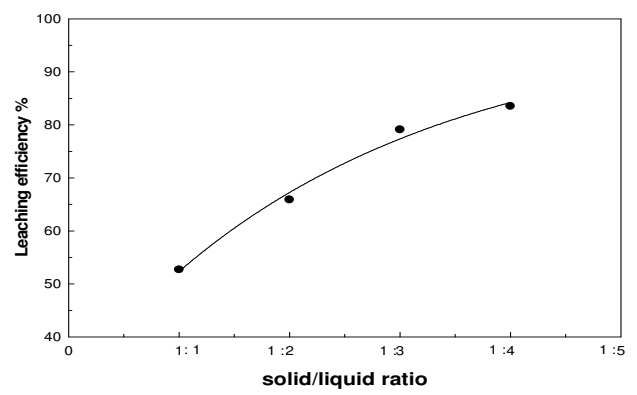

Fig.10: Effect of solid \liquid ratio on the leaching percent of uranium from the studied El Sela kaolinized granite ore material

turn affecting the leaching rate. The effect of the grain size was thus studied in the range of $(-0.4+0.3) \mathrm{mm}$ down to less than $0.1 \mathrm{~mm}$, while the other leaching conditions were fixed at a solid liquid ratio of 1:3 for 2 hours agitation time and $60 \mathrm{~g} \backslash \mathrm{L}$ acid concentration at $25^{\circ} \mathrm{C}$. From the obtained results plotted on Fig. (11), it is clear that there is a significant increase in uranium leachability from $39.5 \%$ to $61.5 \%$ by increasing the ore fineness from $(-0.4+0.3) \mathrm{mm}$ to $(-0.3+0.2)$ $\mathrm{mm}$, respectively. Further, increasing in the grain size fineness down to $(-0.2+0.1)$ and to 


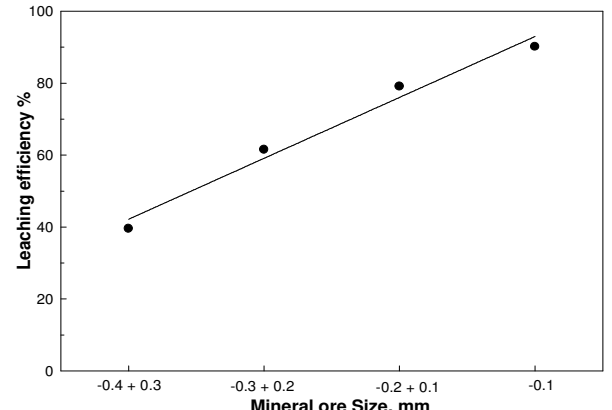

Fig.11: Effect of particle size on the leaching percent of uranium from the studied El Sela kaolinized granite ore material

less than $0.1 \mathrm{~mm}$ has increased the uranium leachability to 79.1 and $90.1 \%$, respectively. This can be explained by increasing the uranium minerals surface area as well as liberation of the adsorbed uranium in a manner that would permit better uranium dissolution. Therefore, $-0.1 \mathrm{~mm}$ grain size is the best one for uranium leaching effeciency.

\section{Effect of temperature}

Four acid leaching experiments have been performed to investigate the effect of leaching temperature upon uranium leaching efficiency in the range from room $\left(25^{\circ} \mathrm{C}\right)$ up to $120^{\circ} \mathrm{C}$, while the other leaching conditions were fixed at a solid liquid ratio of 1:3 for 2 hours agitation time and using a grain size of $-0.1 \mathrm{~mm}$ and $60 \mathrm{~g} \backslash \mathrm{l}$ acid concentration. From the obtained results shown on Fig (12), it was found that the uranium leaching efficiency increases with the increase in temperature, where it increased from $90.1 \%$ at $30^{\circ} \mathrm{C}$ to $98.15 \%$ at $80^{\circ} \mathrm{C}$ and remained almost constant thereafter. It can thus be mentioned that an optimum leaching temperature of copper and uranium under the above mentioned conditions would be $80^{\circ} \mathrm{C}$.

Summing up, it has to be mentioned that the increase in uranium leaching efficiency by

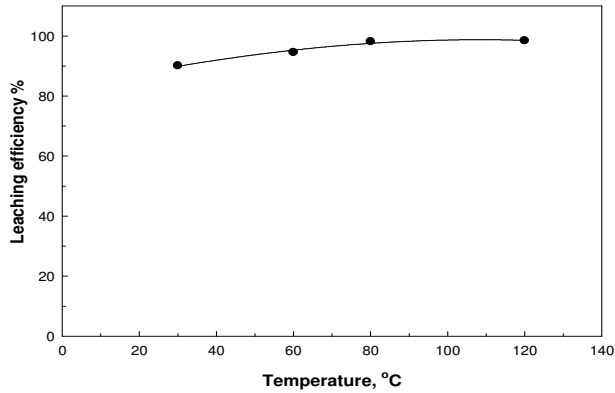

Fig.12: Effect of tempreture on the leaching percent of uranium from the studied El sela kaolinized granite ore material

increaseing the temperature can be an interpretation for the direct effect of the the adsorbed uranium values upon the clay and iron oxides as the effect of the finer ore grinding. However, in order to economize in the studied agitation leaching procedure, it might be possible to achieve almost complete uranium leaching under the obtained optimum conditions.

From the above studied leaching factors of the working technological Bulk sample, it can be concluded that the optimum leaching conditions for about $98 \%$ leachability of uranium would be summarized as follows:

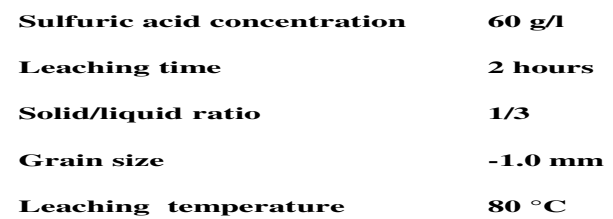

\section{Leaching Results of the Beneficiated} Products

The two obtained ore fractions of the studied El Sela kaolinized granite sample after physical concentration by the froth flotation technique have been subjected to agitation leaching using the optimum conditions obtained for the bulk sample at different temperature. The float fraction (mainly kaolinite) 
weighing about $35.3 \%$ of the original ore sample weight and assaying a total uranium concentration of $1350 \mathrm{ppm}$ has resulted in a uranium leaching efficiency of only $98 \%$ while the sink concentrate (secondary uranium minerals would be concentrated) weighing about $64.7 \%$ of the original ore material sample weight and with a uranium assay of 6300 ppm has resulted in 98\% uranium leaching efficiency (Table 4).

Table 4: Effect of temperature on the leaching efficiency of uranium from the sink and float beneficiated fractions of the studied El Sela kaolinized granite ore material

\begin{tabular}{lrr}
\hline Temp. ${ }^{\circ} \mathrm{C}$ & & U Leaching \% \\
& Sink fraction & Float fraction \\
\hline 25 & $\mathbf{8 9 . 3}$ & $\mathbf{4 2 . 6}$ \\
60 & $\mathbf{8 8 . 3}$ & $\mathbf{7 2 . 2}$ \\
80 & 98.0 & 98.0 \\
120 & 98.0 & 98.3 \\
\hline
\end{tabular}

Increasing the leach liquor temperature to $80^{\circ} \mathrm{C}$ upon the two obtained ore fractions indicated an almost no effect upon the uranium leaching efficiency of the sink fraction. These results indicate that a relatively high temperature $\left(80^{\circ} \mathrm{C}\right)$ is necessary for uranium dissolution from its adsorbed mineral components.

Applying the obtained optimum conditions upon the original sample without physical upgrading achieved 98\% uranium leaching efficiency at $80^{\circ} \mathrm{C}$, indicated that there is no requirement for the prior physical concentration of the ore.

\section{CONCLUSIONS}

The mineralogical study of the kaolinized granite of El Sela sample has indeed revealed that uranium occurs in two modes of occur- rence, namely a mineralized one which is represented by secondary uranium minerals as the uranophane, the meta-autunite and the phurcolite minerals while the second one is manifested in the form of uranium adsorbed upon the surface of kaolinite.

The uraniferous kaolinized granite ore material of El Sela area assaying about $0.454 \%$ uranium has first been subjected to a detailed study of its acid agitation leaching characteristics using sulfuric acid. The purpose is to optimize the relevant agitation leaching factors by realizing the maximum possible uranium leachability. Then the second one is to apply the optimum conditions of the uranium leaching factors of the bulk sample on the beneficiated products of froth flotation technique (sink and float). The latter step is to compare between agitation leaching efficiency of uranium between the bulk sample and physical beneficiated sample.

The agitation leaching efficiency of uranium from the bulk sample in sulfuric acid solution was indicated that the maximum uranium leaching efficiency $98 \%$ was done under conditions of 2 hours agitation time using $60 \mathrm{~g} / \mathrm{L}$ sulphuric acid concentration, 1:3 solid \liquid ratio, $80{ }^{\circ} \mathrm{C}$ leaching temperature and $-0.1 \mathrm{~mm}$ grain size .

The total uranium leachability percent of the beneficiated fractions of froth flotation process was nearly as the same of the agitation leaching of the bulk sample so, there is no need for the prior physical dressing of the ore.

\section{REFERENCES}

Abd Elaal, H. A., (2006):" Geochemistry and processing of some valuable metals from mineralized two mica granites,South Eastern Desert, Egypt" M. Sc. Thesis Faculty of Science, Cairo University.

Abdel Meguid, A.A.; Ammar, S.E.; Ibrahim, T.M.; Gamal, K.A.; Gaafar, I.M.; Masoud, S.M.; Khamis, A.; Omer, S. A.; Haridy, M.H.; Shahin, 
H.A.; Aly, E.M.; Kamel, A.I.; Mostafa, B.M., and Abdel Gawad, A.,2003. "Uranium potentiality of the Eastern Desert granites, Egypt. Internal report NMA, 311p.

Gharib, M. E.; Masoud, M. S.; Attaia, G. E.; Atress, M. S.; Hassan, M. A., and Fawzy, M. M., 2013. Mineralogical fractionation of kaolinized granite of El Sela area, South Eastern Desert, Egypt. Egypt. J. Geol., 57.

Hefnawy, M. A.; El-Said, M.; Hussein, M., and Amin, M. A., 2002. Fungal leaching of uranium from its geological ores in Alloga area, West Central Sinai, Egypt. On Line J. Biol. Sci., 2 (5), 346-350.

Ibrahim, M.E.; Zalata, A.A.; Assaf, H.S.; Ibrahim, I.H., and Rashed, M.A.,2003. El Sella shear zone, South Eastern Desert, Egypt: An example of vein-type uranium deposit. Egypt. J. Geol., 42/2, 690-704.

International Atomic Energy Agency (IAEA), 1993. Uranium Extraction Technology. Technical Re- ports Series No. 359 .

Masoud, M. S.; Gharib M. E.; Attaia G. E.; Atress M. S.; Hassan M. A., and Fawzy M. M., 2012. Physical upgrading of uranium from El Sela kaolinized granite, South Eastern Desert, Egypt. Egypt. J. Geol., 56, 559-568.

Merritt, R.C., 1971. In: The Extractive Metallurgy of Uranium, Colorado. School of Mines Res. Inst., Golden, Colorado, 83p.

Shapiro, L., and Brannock, W. W.,1962. Rapid analysis of silicates, carbonates and phosphates rocks. U.S. Geol. Survey Bull, 1144 (A), 56 P.

U.S. Energy Information Administration (EIA), 2011. International Energy Outlook (2011): Available online: http://www.eia.gov/forecasts/ ieo/pdf/0484(2011).pdf

Yousef, L.A.; Abdel Ghany, M.S., and Afifi, S.Y.,2013. Recovery of Uranium (VI) From Treated Technological Sample, El Sela Area, South Eastern Desert, Egypt. Arab J. Nuclear Science and Applications, 46(3), 40-51

\section{الاذابة الحامضية لليورانيوم من الجرانيت المتكولن بمنطقة السيلا جنوب الصحراء الثرقية مصر}

$$
\text { محمد دمرداش هاثم ، رضا عبد الثهيد غزالة و منى محمد فوزى }
$$

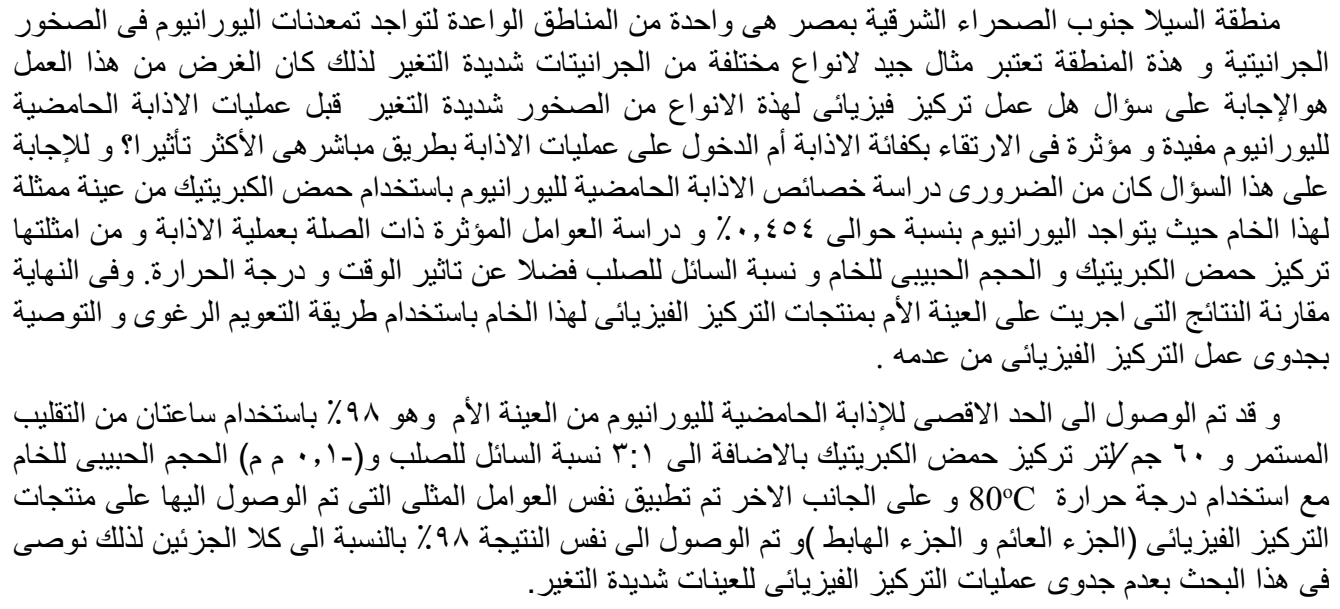

